\title{
Analisis Kesalahan Konsep Pecahan Pada Siswa Kelas VII A SMP NEGERI 13 SATU ATAP TANJUNGPINANG
}

\author{
Alifah Yulianingsih', Febrian² dan Alona Dwinata ${ }^{3}$ \\ 1,2,3 Program Studi Pendidikan Matematika, FKIP, Universitas Maritim Raja Ali Haji \\ Jl Raya Dompak, Tanjungpinang, 29124, Provinsi Kepulauan Riau, Indonesia \\ 1alifah.yulianingsih.ay@gmail.com
}

\begin{abstract}
Abstrak
Studi ini bertujuan untuk mengetahui kesalahan konsep pecahan pada siswa dengan menganalisis lebih dalam kesalahan yang siswa lakukan saat mengerjakan beberapa soal yang diberikan, sehingga studi ini mengambil desain studi kasus, dengan mengambil subjek studi siswa kelas VII A SMP Negeri 13 Satu Atap Tanjungpinang yang berjumlah 30 orang. Instrumen yang digunakan adalah tes dan wawancara, tes yang digunakan merupakan tes jawaban singkat dan tes uraian yang berjumlah 14 soal dengan indikator soal yang berbeda-beda, untuk membantu peneliti mengetahui lebih dalam cara berfikir siswa saat mengerjakan tes maka digunakan instrumen wawancara terstruktur terbuka dengan bantuan alat perekam suara (audio recorder). Hasil analisis yang dilakukan ditemukan bahwa siswa melakukan kesalahan konsep dihampir semua soal dengan persentasi kesalahan di soal 1 sebesar $62 \%$, soal 3 sebesar $80 \%$, soal 4 sebesar $25 \%$, soal 5 sebesar $50 \%$, soal 6 a dan 6 c sebesar $83 \%$, soal $6 b, 6 d$, 6e sebesar $100 \%$, dan soal cerita di soal 8 dan 9 sebesar $86 \%$ dan $7 \%$.

Kata Kunci: kesalahan konsep, pecahan, SMPN 13 satap TPI
\end{abstract}

\begin{abstract}
This study aims to find out the fraction of the concept of fractions in students by analyzing more in the mistakes that students do while working on some given questions, so this study takes the case study design, by taking the subject of the study of class VII A SMP Negeri 13 Satu Atap Tanjungpinang which amounted to 30 people. The instruments used were tests and interviews, the test used was a short answer test and a 14 description test with different problem indicators, to help researchers know more in the way students think when doing the test then used an open structured interview instrument with the help audio recorder. The result of the analysis found that the students did the mistake of the concept in almost all the problems with the percentage of error in problem 1 of $62 \%$, the problem 3 by $80 \%$, the problem of 4 by $25 \%$, about 5 by $50 \%$, about $6 a$ and $6 c$ by $83 \% 6 b, 6 d, 6 e$ by $100 \%$, and the story in problem 8 and 9 is $86 \%$ and $7 \%$

Keyword: concept error, fractional, SMPN 13 satap TPI
\end{abstract}




\section{Pendahuluan}

Proses pembelajaran tidak dapat terlepas dari kegiatan guru mengevaluasi dan melakukan penilain pembelajaran, jika siswa mendapatkan hasil belajar yang memuaskan dan mencapai kriteria ketuntasan yang telah ditetapkan oleh guru maka pembelajaran tersebut dapat dikatakan efektif dan sukses, seperti yang dinyatakan Arifin (2014) dalam sistem pembelajaran, evaluasi merupakan salah satu komponen penting dan tahap yang harus ditempuh guru untuk mengetahui keefektifan pembelajaran.

Evaluasi pembelajaran dapat dilakukan dengan teknik tes maupun nontes. Berdasarkan hasil evaluasi, guru dapat mengetahui kesalahan siswa yang mungkin muncul dalam usaha memahami konsep dari materi yang diberikan. Dalam Suryaningrum dan Febrian (2016) Sukirman menyatakan bahwa kesalahan merupakan penyimpangan terhadap halhal yang benar yang sifatnya sistematis, konsisten, maupun insidental pada daerah tertentu. Kesalahan yang sistematis dan konsisten terjadi disebabkan oleh tingkat penguasaan materi yang kurang pada siswa. Sedangkan kesalahan yang bersifat insidental adalah kesalahan yang bukan merupakan akibat dari rendahnya tingkat penguasaan materi pelajaran, melainkan oleh sebab lainnya seperti kurang cermat dalam membaca untuk memahami maksud soal, kurang cermat dalam menghitung atau bekerja secara tergesagesa karena merasa diburu waktu yang tinggal sedikit. Untuk itu perlu adanya analisis kesalahan konsep pada siswa dalam menyelesaikan permasalahan agar dapat diketahui letak kesalahan yang dilakukan oleh siswa.

Kesalahan konsep merupakan salah satu kategori kesalahan berdasarkan teori Newman, yaitu Comprehension error (kesalahan memahami) yang terjadi karena siswa kurang memahami terutama dalam konsep suatu materi (Arifani dkk, 2016)

Berdasarkan teori hadar kesalahan konsep juga masuk dalam kategori kesalahan menurut teorinya yaitu Distorted theorem or definition (kesalahan dalam menggunakan definisi atau teorema) merupakan penyimpangan dari prinsip, aturan, teorema, konsep atau definisi pokok yang khas (Hadar 1987).

Dalam studi ini, materi yang ingin diteliti kesalahan konsepnya adalah materi pecahan karena berdasarkan hasil ujian semester ganjil, sebagian besar siswa kelas VII SMP Negeri 13 Satu Atap Tanjungpinang menjawab salah pada materi pecahan. Materi pecahan masih menjadi materi yang sulit bagi siswa. Hal ini sejalan dengan pendapat Mark (1988) dalam (Hadi, 2016) yang menyatakan bahwa konsep pecahan merupakan topik yang lebih sulit dibandingkan dengan bilangan bulat. Dalam mempelajarinya, sering terjadi miskonsepsi pada diri siswa (Hadi, 2016).

Adapun tujuan dari studi yang dilakukan ini ialah untuk mengetahui kesalahan konsep pecahan pada siswa kelas VII A SMP Negeri 13 Satu Atap 
Tanjungpinang, dengan focus pada bentuk kesalahan konsep yang dilakukan siswa pada masing masing indikator soal dan besar persentase siswa yang melakukan kesalahan konsep pada masing masing indikator soal tersebut.

\section{Metode}

Penelitian ini berpendekatan kualitatif dengan sifat deskriptif. Penelitian deskriptif merupakan penelitian yang dimaksudkan untuk mengumpulkan informasi mengenai status suatu gejala yang ada, yaitu keadaan gejala menurut apa adanya pada saat penelitian dilakukan (Prabawati, 2018). Studi ini bertujuan untuk mengetahui kesalahan konsep pecahan pada siswa dengan manganalisis lebih dalam kesalahan yang siswa lakukan saat mengerjakan beberapa soal yang diberikan, sehingga studi ini mengambil desain studi kasus yang mana menurut Rawambaku (2015: 26) Studi kasus bertujuan untuk mempelajari secara intensif mengenai unit sosial tertentu yang meliputi individu, kelompok, lembaga, dan masyarakat.

Studi ini dilaksanakan pada siswa kelas VII A SMP Negeri 13 Satu Atap Tanjungpinang yang berjumlah 30 orang dengan 17 orang perempuan dan 13 orang laki-laki.

Instrumen yang digunakan adalah tes dan wawancara, tes yang digunakan merupakan tes jawaban singkat dan tes uraian yang mana setiap langkah yang dilakukan subjek studi dapat terlihat dalam jawaban, sehingga dapat diketahui dengan jelas kesalahan konsep yang dilakukan subjek studi, tes yang diberikan berjumlah 14 soal dengan indikator soal yang berbeda-beda. Untuk membantu peneliti mengetahui lebih dalam cara berfikir siswa saat mengerjakan tes maka digunakan instrumen wawancara terstruktur terbuka dengan bantuan alat perekam suara (audio recorder).

Proses analisis diawali dengan mengkoreksi jawaban siswa sehingga studi dapat difokuskan pada jawaban siswa yang salah saja, kemudian dari jawaban siswa yang salah dicari kesalahan yang masuk dalam kategori kesalahan konsep untuk melihat bentuk kesalahan konsep yang dilakukan siswa dan berapa persentase kesalahan konsep pada masing-masing indikator soal, kemudian dilakukan wawancara kepada siswa yang melaukan kesalahan agar dapat mengetahui lebih dalam cara berfikir siswa tersebut.

\section{Hasil dan Pembahasan}

Terdapat 30 siswa dalam subjek penelitian. Kesalahan konsep yang terjadi pada sebagian siswa dibahas sebagai berikut.

\section{A. Bentuk kesalahan konsep yang dilakukan siswa}

Indikator soal 1 yang berisi pecahan biasa diminta mencari pecahan senilainya ditemukan bahwa, siswa mengalikan pecahan yang ingin dicari pecahan senilainya dengan pecahan yang memiliki pembilang atau penyebut 40, sehingga dikategorikan kedalam kesalahan konsep. 
Pecahan yang senilai dengan pecahan $\frac{2}{8}$ tetapi memiliki penyebut lebih dari 40 adalah $\frac{2}{8} \times \frac{10}{8}=\frac{2 \times 20}{0}: \frac{80}{8}: 8=\frac{10}{1}$

Gambar 1. Penyelesaian siswa 8 pada soal 1

Indikator soal 3 yang berisi beberapa pecahan biasa diminta mengurutkan beberapa pecahan tersebut ditemukan bahwa, urutan yang siswa berikan tidak sesuai dengan yang diminta dalam soal, sehingga dikategorikan kedalam kesalahan konsep.

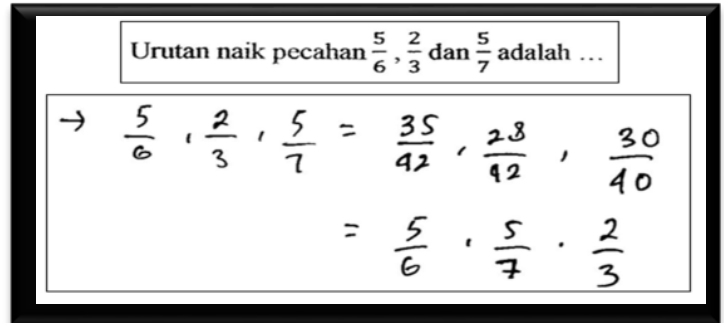

Gambar 2. Penyelesaian siswa 29 pada soal 3

Indikator soal 4 yang berisi sebuah pecahan campuran diminta mengubah ke pecahan biasa ditemukan bahwa, Siswa hanya memberikan penyelesaian untuk mencari pembilang saja itupun dengan cara penyelesaian yang salah, sehingga dikategorikan kedalam kesalahan konsep.

Pecahan biasa dari $34 \frac{1}{7}$ adalah ...

$1 \times 3 u+7=41$

Gambar 3. Penyelesaian siswa 13 pada soal 4

Indikator soal 5 yang berisi sebuah pecahan campuran diminta mengubah ke desimal ditemukan bahwa, siswa membagi pembilang ke penyebut tetapi hasil bagi yang siswa dapatkan salah karena dari hasil wawancara didapati siswa tidak dapat menghitung dengan pembagian bersusun, sehingga dikategorikan kedalam kesalahan konsep.

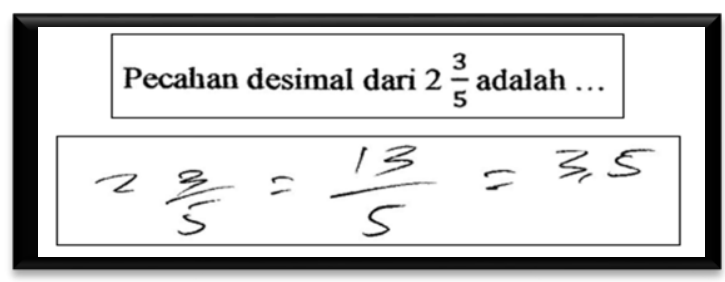

Gambar 4. Penyelesaian siswa 8 pada soal 5

Indikator soal 6a yang berisi beberapa pecahan diminta melakukan operasi pengurangan ditemukan bahwa, siswa salah tahapan dalam penyelesaian yang sesuai, sehingga dikategorikan kedalam kesalahan konsep.

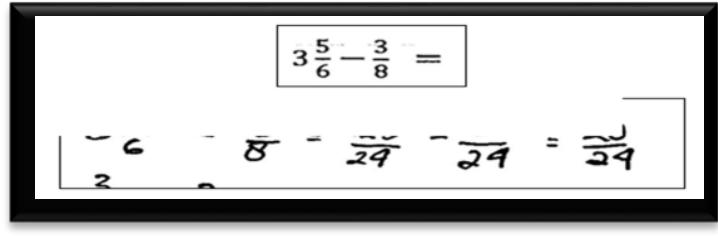

Gambar 5. Penyelesaian siswa 4 pada soal 6a

Siswa juga langsung mengurangkan pecahan biasa yang sudah diubah dari pecahan campuran tanpa menyamakan penyebut menggunakan KPK kedua pecahan tersebut.

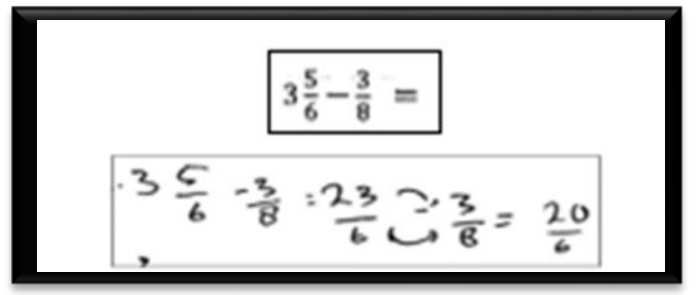

Gambar 6. Penyelesaian siswa 15 pada soal 6a

Mosharafa: Jumal Pendidikan Matematika Volume 7, Nomor 2, Mei 2018 
Terdapat siswa yang sudah tepat dalam urutan penyelesaian soal tapi siswa salah dalam mencari pembilang setelah penyebut disamakan, sehingga juga dikategorikan kedalam kesalahan konsep.

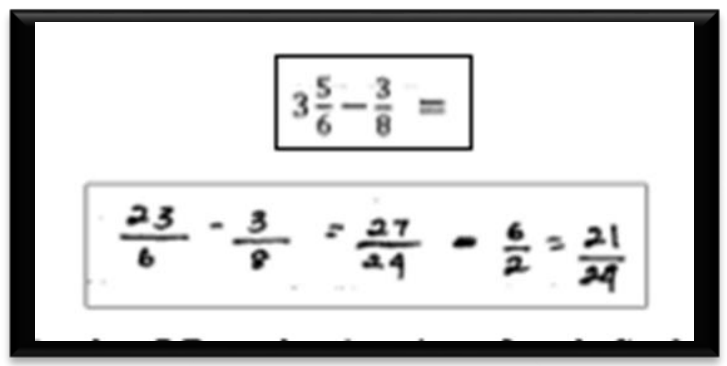

Gambar 7. Penyelesaian siswa 3 pada soal 6a

Indikator soal $6 \mathrm{~b}$ yang berisi beberapa pecahan diminta melakukan operasi perkalian ditemukan bahwa, Siswa menyelesaikan menggunakan aturan penjumlahan dan pengurangan, sehingga dikategorikan kedalam kesalahan konsep.

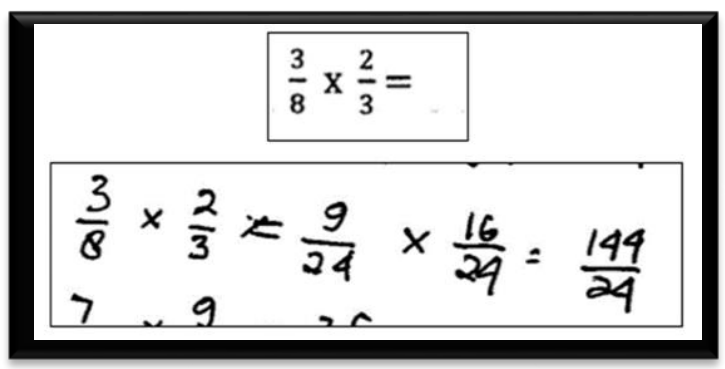

Gambar 8. Penyelesaian siswa 4 pada soal 6b

Dari hasil wawancara Siswa mengalikan dengan cara mengalikan pembilang pecahan pertama dengan peneyebut pecahan kedua untuuk mencari pembilang dan mencari penyebut dengan mengalikan penyebut pecahan pertama dengan pembilang pecahan kedua, sehingga juga dikategorikan kedalam kesalahan konsep.

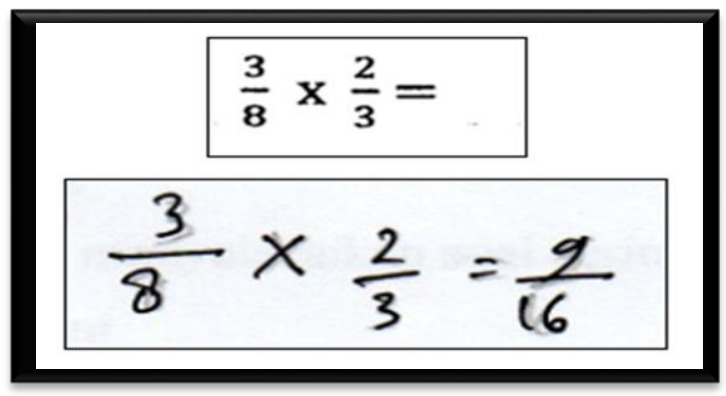

Gambar 9. Penyelesaian siswa 27 pada soal 6b

Indikator soal 6c yang berisi beberapa pecahan campuran diminta melakukan operasi perkalian ditemukan bahwa, Siswa menyelesaikan menggunakan aturan penjumlahan dan pengurangan seperti soal perkalian sebelumnya, sehingga dikategorikan kedalam kesalahan konsep.

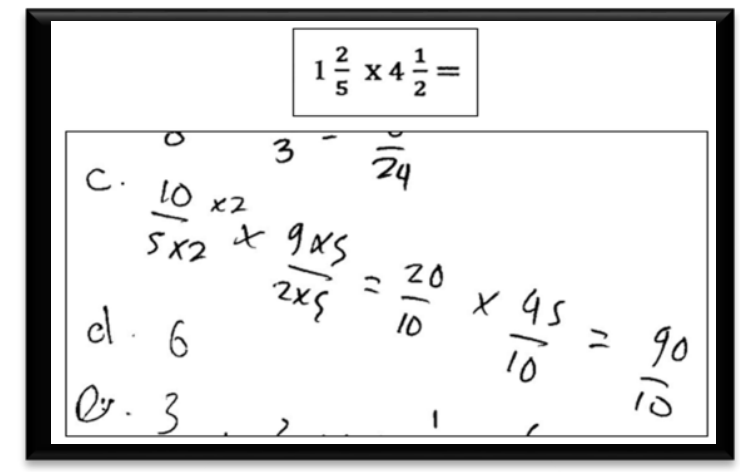

Gambar 10. Penyelesaian siswa 10 pada soal $6 c$

Indikator soal $6 \mathrm{~d}$ yang berisi beberapa pecahan diminta melakukan operasi pembagian ditemukan bahwa, siswa mengubah pembagian menjadi penjumlahan lalu dari hasil wawancara siswa mencari pembilang pada pecahan tersebut dengan mengalikan antara pembilang dan penyebut pecahan sebelumya. 


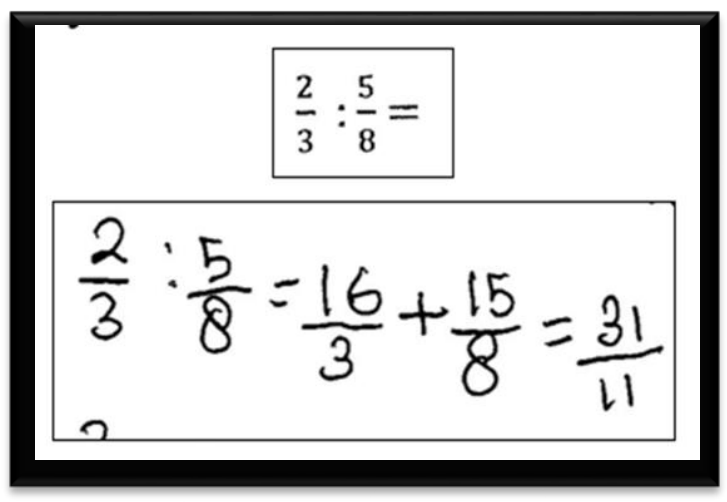

Gambar 11. Penyelesaian siswa 27 pada soal $6 d$

Siswa juga mengubah pembilang menjadi penyebut dan penyebut menjadi pembilang dikedua pecahan, sehingga dikategorikan kedalam kesalahan konsep.

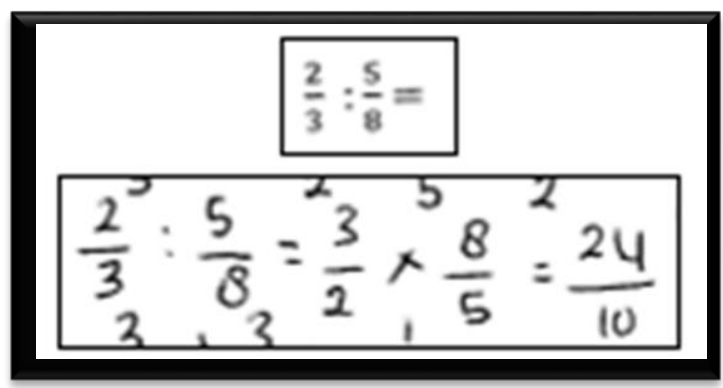

Gambar 12. Penyelesaian siswa 3 pada soal $6 d$

Siswa tetap menyelesaikan menggunakan aturan penjumlahan dan pengurangan dan ada yang langsung membagi pecahan, sehingga juga dikategorikan kedalam kesalahan konsep.

$$
\frac{2}{3}: \frac{5}{8}=
$$$$
\frac{3}{5}+\frac{3}{5} \times 3 \frac{1}{3}=\frac{9}{15}+\frac{9}{15} \times \frac{3}{15}=\frac{59}{15}
$$

Gambar 13. Penyelesaian siswa 24 pada soal $6 d$
Indikator soal 6e yang berisi beberapa pecahan biasa dan campuran diminta melakukan operasi hitung campuran ditemukan bahwa, siswa menyelesaikan soal dengan menyamakan penyebut semua pecahan walaupun didalamnya berisi operasi perkalian, sehingga menyelesaikan seperti penyelesaian penjumlahan dan pengurangan.

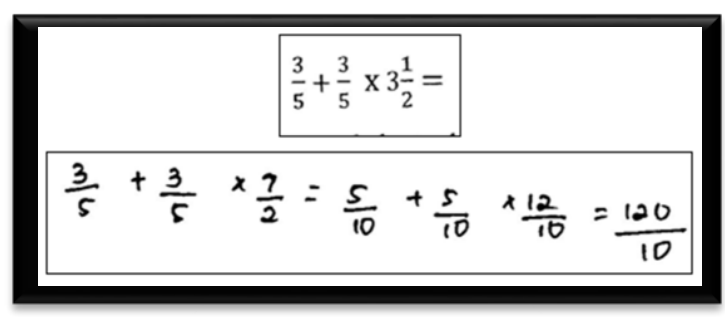

Gambar 14. Penyelesaian siswa 21 pada soal $6 e$

Siswa melakukan kesalahan karena siswa mendahulukan penjumlahan daripada perkalian, sehingga dikategorikan kedalam kesalahan konsep.

$$
\begin{array}{|l}
\frac{3}{5}+\frac{3}{5} \times 3 \frac{1}{2}= \\
\frac{3}{5}+\frac{3}{5} \times 3 \frac{1}{2} \\
\frac{6}{5} \times 3 \frac{1}{2} \\
\frac{6}{5} \times \frac{7}{2}=\frac{42}{10}=4 \frac{2}{10}
\end{array}
$$

Gambar 15. Penyelesaian siswa 28 pada soal 6 e

Indikator soal 8 yang berisi masalah dalam kehidupan sehari-hari yang berkaitan dengan operasi penjumlahan atau pengurangan diminta menyelesaikan masalah tersebut ditemukan bahwa, siswa 
langsung menjumlahkan saja tanpa menghiraukan penyebut yang berbeda.

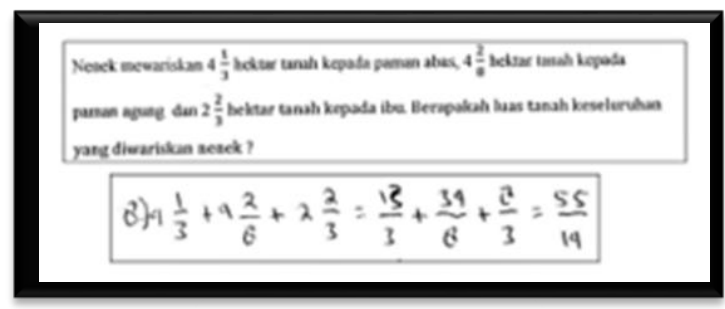

Gambar 16. Penyelesaian siswa 8 pada soal 8

Indikator soal 9 yang berisi masalah dalam kehidupan sehari-hari yang berkaitan dengan operasi pembagian diminta menyelesaikan masalah tersebut ditemukan bahwa, siswa langsung membagi pembilang dengan pembilang dan penyebut dengan penyebut, sehingga dikategorikan kedalam kesalahan konsep.

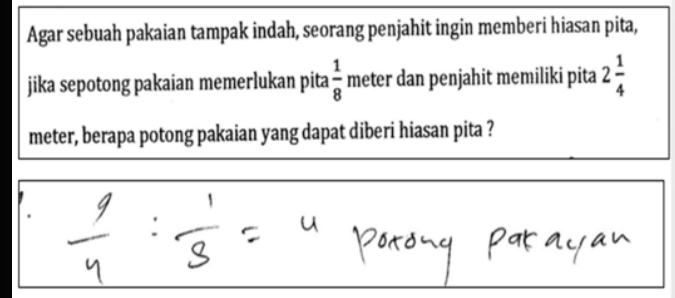

Gambar 17. Penyelesaian siswa 8 pada soal 9

\section{B. Persentase Siswa yang Melakukan Kesalahan Konsep}

Penghitungan persentase yang dilakukan adalah persentase siswa yang melakukan kesalahan konsep dari siswa yang melakukan kesalahan dinomor soal yang dicari persentasenya, sehingga dapat dirumuskan sebagai berikut:

$$
\mathrm{pK}=\frac{\mathrm{nK}}{\mathrm{nS}} \times 100 \%
$$

pK: persentase kesalahan konsep
nK: banyak siswa melakukan kesalahan konsep pada soal $x$

nS: banyak siswa melakukan kesalahan pada soal $\mathrm{x}$

Hasil dari analisis menunjukkan bahwa pada soal 1 siswa yang melakukan kesalahan konsep sebesar 62\%, pada soal 3 sebesar $80 \%$, dan pada soal 4 sebesar $25 \%$, sedangkan pada soal 5 siswa yang melakukan kesalahan konsep sebesar 50\%.

Soal 6 yang berisi operasi hitung pecahan yaitu 6a sebesar $83 \%$ siswa yang melakukan kesalahan konsep, soal 6b sebesar $100 \%$, soal $6 \mathrm{c}$ sebesar $82 \%$, soal $6 \mathrm{~d}$ sebesar $100 \%$ dan soal 6e sebesar $100 \%$ siswa yang melakukan kesalahan konsep.

Soal cerita di soal 8 dan 9 sebesar $86 \%$ dan $7 \%$.

\section{Penutup}

Berdasarkan hasil studi analisis kesalahan konsep pecahan pada siswa kelas VII A SMP Negeri 13 Satu Atap Tanjungpinang dapat dilihat bahwa: 1) Dari 14 soal dengan imdikator soal yang berbeda-beda hampir seluruh soal terdapat kesalahan konsep saat siswa mengerjakannya kecuali pada soal nomor 2, 7 dan 10; dan 2) Persentasi kesalahan konsep yang telah dianalisis disetiap soalnya benilai besar dengan beberapa soal yang keseluruhan kesalahannya merupakan kesalahan konsep yaitu soal nomor 6b, 6d dan 6e yang berisi soal operasi hitung pecahan. 


\section{Daftar Pustaka}

Arifani, N.H., As'ari, A.R., \& Abadyo. (2016). Analisis Kesalahan Siswa Dalam Menyelesaikan Soal Matematika Timss Menurut Teori Newman: Studi Kasus Pada Siswa Kelas VIII SMP Negeri 1 Tanjungbumi Bangkalan. Seminar Nasional Matematika Dan Pendidikan Matematika UNY. Yogyakarta. 05 November 2016.

Arifin, Z. (2014). Evaluasi Pembelajaran: Prinsip, Teknik, Prosedur. Bandung: PT Remaja Rosdakarya Offset.

Hadar, M.N,. Zaslavsky, O,. \& Inbar, S. (1987). Journal for Research in Mathematics Education. An Empirical Classification Model for Errors in High School Mathematics. 18(1). 3-14.

Hadi, S. (2016). Pembelajaran Konsep Pecahan Menggunakan Media Komik Dengan Strategi Bermain Peran Pada Siswa SD Kelas IV Semen Gresik. Diunduh Pada Tanggal, 20.

Prabawati, M. N. (2018). Analisis Kemampuan Literasi Matematik Mahasiswa Calon Guru Matematika. Mosharafa: Jurnal Pendidikan Matematika, 7(1), 113-120.

Rawambaku, H. (2015). Metodologi Penelitian Pendidikan: Dasar-Dasar Analisis Dan Pengolahan Data Statistik. Jakarta: Libri.

Runtukahu, J.T., \& Kandou, S. (2014).

Pembelajaran Matematika Dasar Bagi Anak Berkesulitan Belajar. Yogyakarta: Ar-Ruzz Media.

Suryaningrum, E. A., \& Febrian, F. (2016).

Dual Mode Error Analysis:

Penyelesaian Permasalahan Luas

Permukaan Serta Volume Prisma Dan
Limas Siswa Kelas Viii Smp. Jurnal Gantang, 1(2), 25-38. 